\title{
喉頭気管食道裂（type 3）の麻酔経験
}

\author{
松山尚弘*2 広木公一*1 藤原孝憲*1 窪田達也*2 大竹一栄*2
}

\begin{abstract}
要旨 喉頭気管食道裂 type 3 の根治術の麻酔を経験した。この疾患の頻度は，まれではあるが， 放置すれば呼吸器合併症を併発し，致死的転帰をたどる。症例は，3,000 g の女児で, 生後 8 日に 腹部食道結禁術および空腸瘦を造設し, 生後 30 日に一期的根治手術を行なった。麻酔導入後, 気 管内挿管を行ない, 内頸動静脈より膜型人工肺(ECMO) 導入した. ECMO使用により, 非換気 下に食道気管切開後, 術野より特注のY型の気管支用チューブを左右両気管支に挿入し, 逆行性に 経兽気管内择管とした. 術後は筋弛緩阂投与下に人工呼吸により呼吸管理を行ない, 術中, 術後と も経過良好であった。
\end{abstract}

\section{I 緒 言}

喉頭気管食道裂は，喉頭気管の気道と食道との間 の隔壁に裂 (cleft) が存在するまれな奇形で，世 界で現在までに 140 例ほどの報告がある1). 本邦に おいて, 1974 年秋山らの初報告以来 16 例の報告を みるのみである2). なかでも喉頭から気管分岐部に 至るまで裂（cleft）が存在する type 3 は，肺炎か ら, 呼吸不全を起こし, やがて多藏器不全となり, 予後は非常に不良である。この type の根治術の成 功例は, 世界でも数少ない. 今回われわれは, 初め て, 膜型人工肺（ECMO）使用による非換気下の 術中呼吸管理を併用した喉頭気管食道裂の根治術の 麻酔を経験したので報告する。

\section{II 症 例}

妊娠中より羊水過多を指摘されていたため, なん らかの消化管異常を推定されていた。 38 週 4 日に アトニンによる分婏誘発を施行し, 経胵分婏により

*1神奈川県立こども医療センター麻酔科

${ }^{* 2}$ 自治医科大学集中治療部

受理日 1994.3 .31
出生した女児である。出生直後より多呼吸, チア ノーゼがあり, 酸素投与によりチアノーゼはやや改 善し, アプガースコアは, 1 分值 7 点, 5 分值 8 点

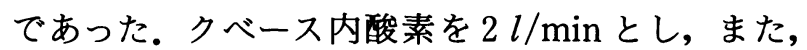
口腔咽頭分泌物多量のため頻回に吸引したが多呼吸 チアノーゼは改善せず, 生後 5.5 時間後, 神奈川こ ども医療センターに救急搬送となった。

入院時, 血液ガスデー夕上, $\mathrm{FiO}_{2}$ 0.3, $\mathrm{pH} 7.280$, $\mathrm{PCO}_{2} 43.0$ torr, $\mathrm{PO}_{2} 80.7$ torr, $\mathrm{BE} 1.0$ と呼吸状態 は改善していた。腹部所見では胃内容は吸引されず 陥凹しており，X-P 上腸管ガスは観察されなかっ た. 出生 3 日になっても腸管ガスがみられなかった ため, 胃管より空気を吹き込んだところ, 腸管のガ スは観察された。ここで, 食道裂孔へルニアを疑い 食道造影を施行したところ, 通常よりも太い食道と ともに左右気管支が同時に描出された（図 1 ).

確定診断を得るために, 生後 8 日に全麻下にて上 部消化管内視鏡を施行した.チオペンタール, サク シニールコリンによる急速導入後気管内挿管した, 挿管時の後頭展開の際には披裂軟骨部に異常は認め なかった，挿管後換気したところ，左右両肺とも良 


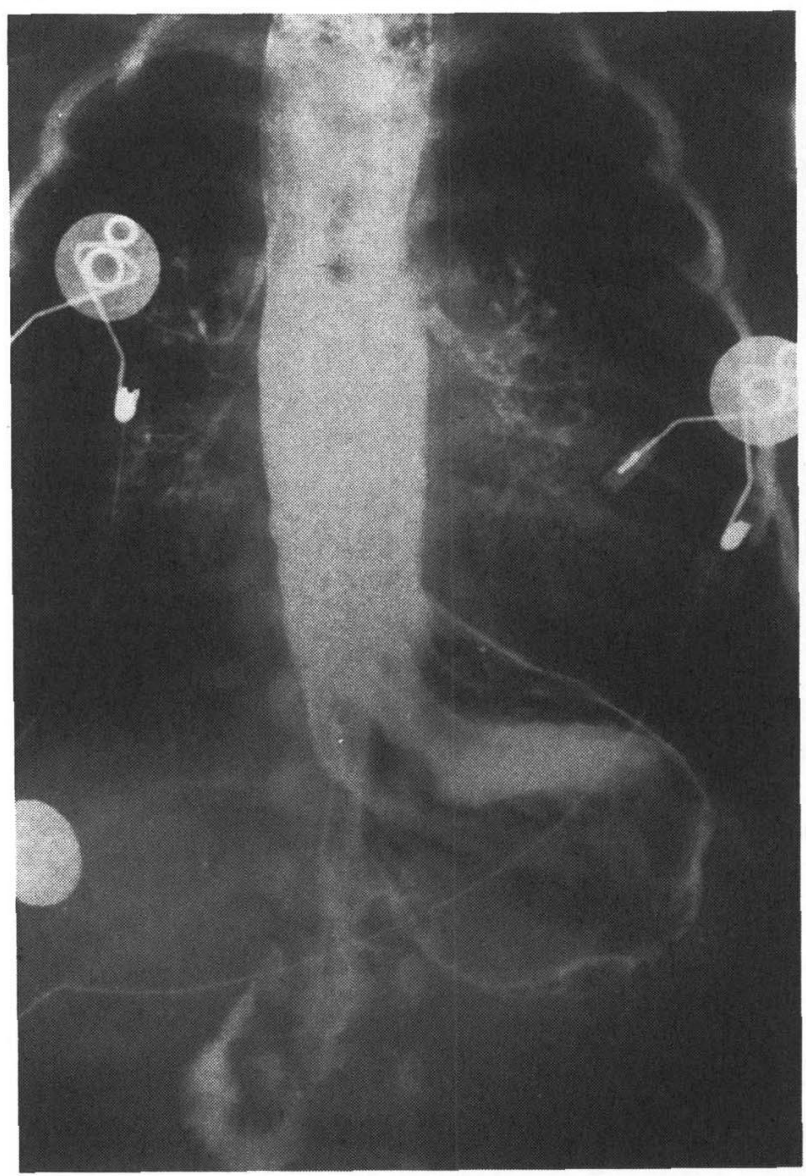

図 1 食道造影所見

通常より太い食道とともに左右気管が同時に描出さ れた。

好な換気が得られ腹部の膨隆もなかった。内視鏡挿 入後食道内に気管チューブがみられ，さらにチュー ブの先端より末梢側に左右の気管支孔が観察された (図 2 )。

再度，喉頭部を観察したところ，披裂軟骨部正中 に裂（cleft）が観察された（図 3 )。喉頭より気管 分岐部に至る喉頭気管食道裂（type 3）であること を確認し, 誤嚥性肺炎の予防のため, 腹部食道結禁 術および空腸瘻を造設した。

術後, 食道盲端より誤嚥性肺炎予防のため唾液の 低圧持続吸引を行ない，経管栄養にて成長を待った うえで根治術を行なうこととした。生後 16 日頃よ り食道結禁が驰み，盲端部と胃とが交通しはじめ, 誤臙性肺炎を併発することが懸念された。

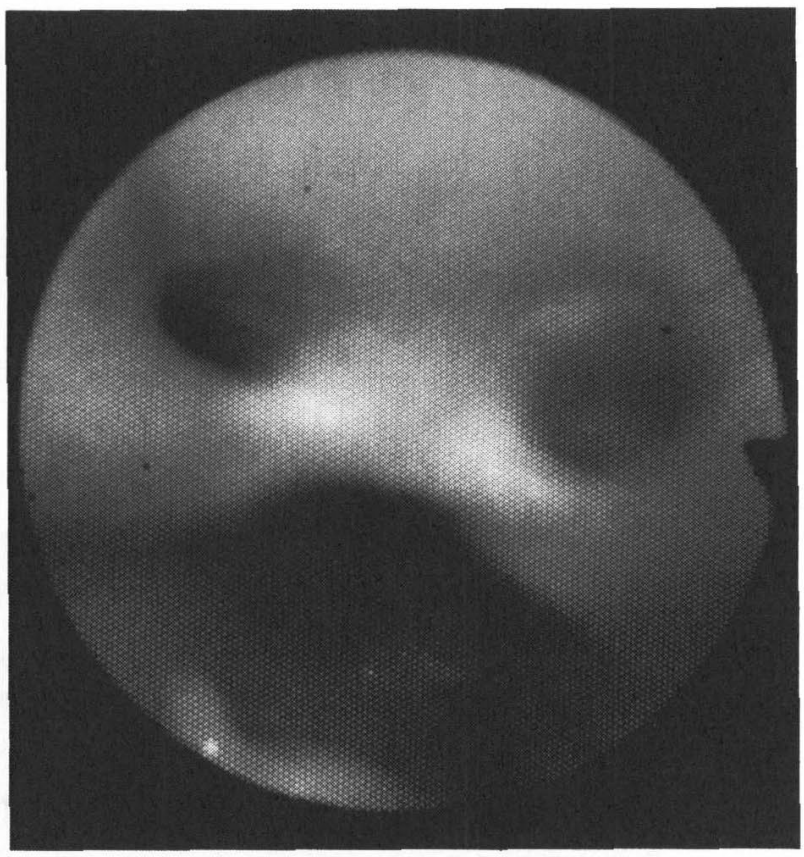

図 2 食道内視鏡所見

食道前面に左右気管支孔が観察される. 気管支孔の 下面にみえるのは食道後壁である。

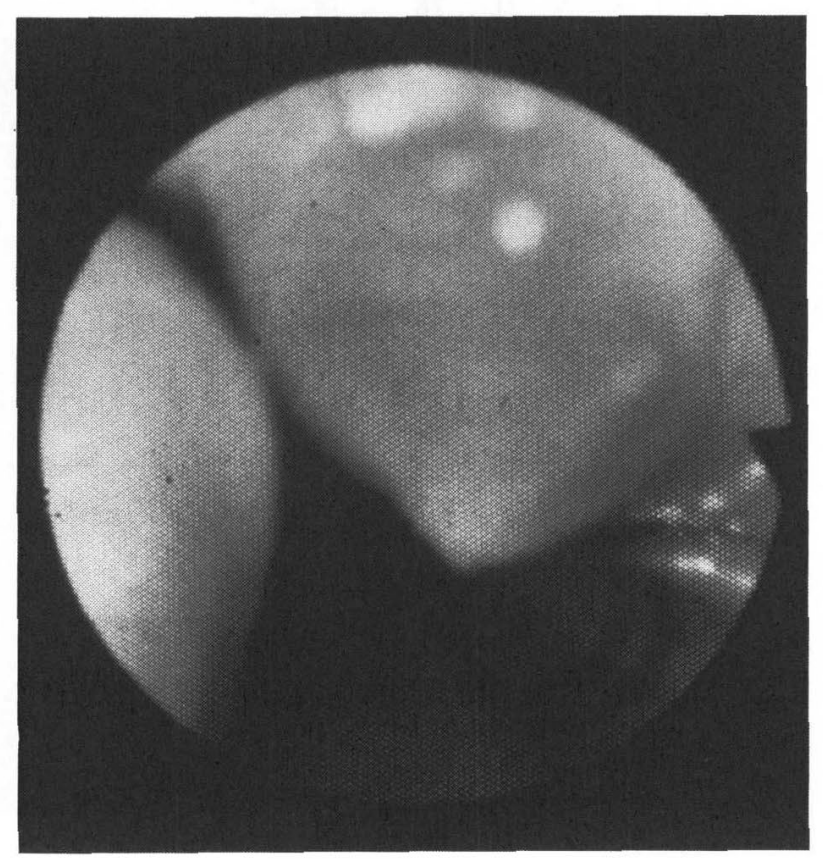

図 3 喉頭内視鏡所見

披裂軟骨部正中に裂が観察された。右下方にみえる のは裂により気管から食道に落ち込んだ気管内 チューブである。 
(1)

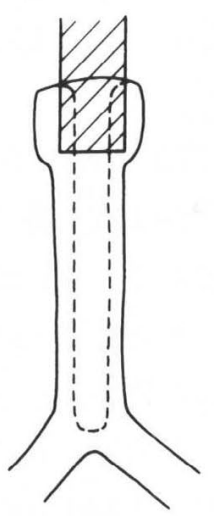

ECMOにより 呼吸停止

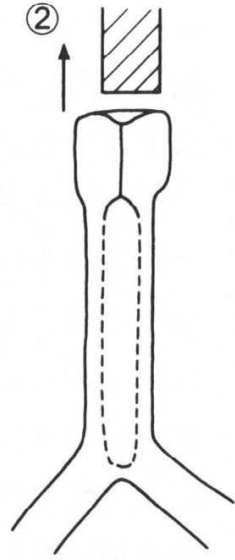

挿管チューフを

咽頭まて引き抜き，

喉頭正中切開して

喉頭食道裂䋖合
(3)

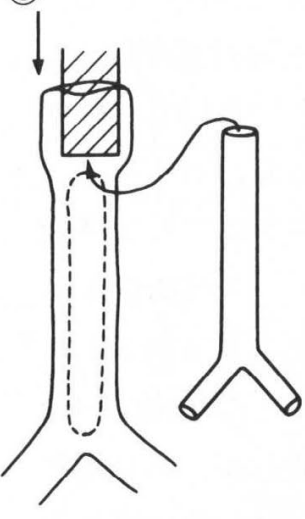

術野より特注Y字チューフを

逆行性に挿管し,

上方よりの插管チューフに

固定し引き抜く
(4)

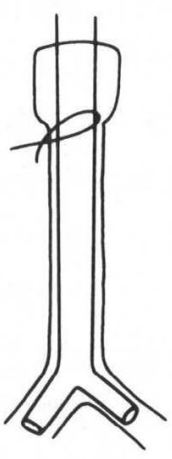

換気可能てある

ことを確認し，

気管食道裂䋖合

喉頭部で前壁に

一針䋖合

図 4 手術手技と挿管チューブの操作

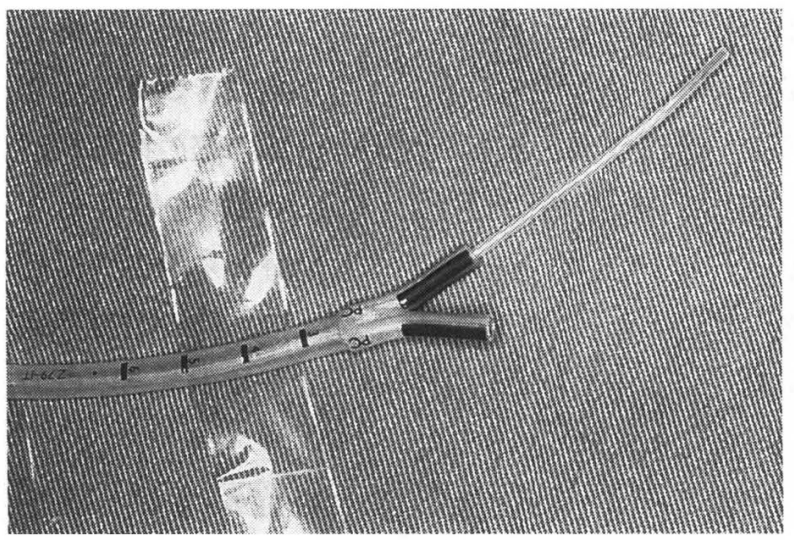

図 5 使用した Y 型のチューブ

気管部分はポルテックス社製 4.0 , 気管支部分は 3.5 のサイズのものを、気管内吸引チューブが左右に通 るように作成したものである.

生後 30 日, 体重 $3,000 \mathrm{~g}$, 身長 $48.5 \mathrm{~cm}$ のとき に根治術を施行した。術前検査で, 血液生化学, 心 電図では, 特に問題はなかった。

\section{III 麻酔経過}

チオペンタール $10 \mathrm{mg}$, ベクロニウム（vecuronium： $\mathrm{Vb}) 0.6 \mathrm{mg}$ による急速導入後, 経鼻挿管 し, 笑気, フェンタニール, $\mathrm{Vb}$ で維持した。右内 頸静脈に, クラレ社製シンオーレカテーテル $10 \mathrm{~F}$
を挿入し, 先端を右心房に留置し, 右内頸動脈に アーガイル社製トロッカーカテーテル $10 \mathrm{~F}$ を挿入 し，キャピオックス社製人工肺を用いて ECMO を 開始した。 ECMOのフローが得られ，循環の暗転 を確認した時点で換気を中止した. ECMO 中の維 持は，モルヒネ（morphine）とVbで維持した。

手術手技と挿管操作の模式図を図 4 に示す。気管 内挿管後, ECMO のフローが得られた後, 換気を 停止した (1)). 頸部切開後, 挿管チューブを咽頭 まで引き抜き, 甲状軟骨正中切開し, 喉頭食道瘦閉 鎖した（2)．閉創した後，左側臥位とし右第四助 間で開胸し気管食道を切開した後, 特別に作成した Y 型気管支チューブ（図 5 ) の末梢側を両左右気管 支に，中枢側は上方よりの挿管チューブに固定し， 引き抜き, 経鼻挿管となるよう術野より逆行性に挿 管した（3)． $100 \mathrm{cmH}_{2} \mathrm{O}$ 程度の陽圧にて明らかな リークはみられなかったので, この時点より肺の虚 脱を予防するために, ECMO と純酸素下調節呼吸 の併用により呼吸管理を行ない, 気管食道裂を縫合 した (4)).

閉胸し, ECMO を中止し, $\mathrm{FIO}_{2} 1.0$ のもとに, $\mathrm{PO}_{2} 191.1$ torr, $\mathrm{PCO}_{2} 28.3$ torr であったので内頸 動静脈のカニューレを抜去して手術を終了した。終 
了時，気管内分泌物が多いため気管内洗浄を行なっ た. 手術時間 9 時間 20 分, 麻酔時間 11 時間 0 分, ECMO 時間 7 時間 53 分, 出血量 $1,054 \mathrm{ml}$, 輸血 量 $1,115 \mathrm{~m} l$, 輸液量 $400 \mathrm{~m} l$ であった。

術後は, ICUにて筋弛緩薬投与下にて人工呼吸 管理とし, 胸部 $\mathrm{X}-\mathrm{P}$ 上, $\mathrm{Y}$ 型チューブが挿管され 左右両肺が無気肺もなく, 十分換気されているのが 観察された. 術後 16 日にY型チューブを抜管し, シングルチューブを改めて経鼻挿管した。再び筋弛 緩薬投与下に人工呼吸管理とし, 術後 39 日目に抜 管した。

\section{IV 考 察}

喉頭気管食道裂は，喉頭気管と食道との間の隔壁 に裂隙が存在するまれな奇形である，本症は，胎生 28 日から 33 日にかけて気管と食道の分離が完成さ れた後, 輪状軟骨が癒合し喉頭が形成されるが, そ のいずれかの時期に発育が停止したために起こると されている゙).

Pettersson は, 裂隙の程度により次の 3 型に分 類した ${ }^{4)}$.

type 1: 喉頭食道裂. 裂隙が喉頭と食道の間に限 局している型.

type 2 : 部分喉頭気管食道裂。裂隙は気管軟骨に 達しているが, 胸郭外に存在する型.

type 3 : 全喉頭気管食道裂。裂隙が胸郭内気管に 達している型.

またその発生頻度は, Wolfson ら5゙よれば, type $131 \%$, type $247 \%$, type $322 \%$, とされて いる. 多くの場合症状は, 裂隙の大きさや合併症に より異なるが, 無呼吸, チアノーゼ, 哺乳時の chocking, 流延過多, また弱々しい啼泣や発声異 常がみられる。

診断が確定したら気道確保と胃瘦造設を行ない, 肺炎の予防と栄養の確保をするのが治療の原則であ る. ある程度成長を待った後, 根治手術を行なうこ とが多い. 欧米の報告では, 生後 4 日から 13 月月 にわたり, 早期手術が多くなっている ${ }^{6)}$. 当症例も
成長を待っていたが，唾液量が増え，誤嬩性肺炎を 併発しはじめたため, 生後 30 日で根治術を行なう こととした。

type 3 の根治術の際の術中麻酔管理での問題点 は，気管と食道が 1 本の管であるため術中に換気不 全になることである. Donahoe ら゙，今回われわ れが使用したものと同様のY型チューブを使用し, 良好な呼吸管理を得た。しかし，Y型チューブを使 用する際には，術野からのチューブ挿管のため，気 管食道切開を行なう際に一時的に換気ができなくな るという点が懸念された。また，堀本ら孚による， 意識的な片肺挿管による一側肺換気により管理した 例がある。一側換気のときには, $\mathrm{PaO}_{2}$ が低下する 恐れがある点と, 術中無気肺による術後の呼吸器合 併症を引き起こす可能性が高い点が心配された。そ こで, 今回われわれは, ECMOによるガス交換と Y 型チューブの使用とを併用する方法を試みた。こ の方法の利点は, 気管と食道の分離の際の換気が不 可能なときに, ECMOによりガス交換を行ないう る点, そして，Y型チューブを術野から逆行性に気 管内挿管した後換気を行なうことで，肺の虚脱時間 を減らし術後の肺合併症を少しでも減少させる点の 二点と考えられた。

予後については, 重篤な合併症がないかぎり type 1,2 の治療成績は向上しているが, type 3 は きわめて不良である。生存例は, 海外で 3 例7),9),10) 本邦で自験例を含めて 2 例2)である.

\section{$\mathrm{V}$ 結 語}

1. 喉頭気管食道裂 type 3 の根治術の麻酔を経験 した。

2. ECMO 使用し非換気下に一期的根治手術を行 なった。

3. 術野より特注のY 型の気管支換気用チューブを 挿入し, 術後も人工呼吸とした。

4. 術中, 術後とも経過良好であった。 


\section{参考文献}

1) 上村貞繁, 河野澄男: 喉頭気管食道裂一 1 手術成功例 と文献報告の検討一。少外科 $20: 569,1988$

2 ) 秋山洋, 小平義彦, 佐伯守洋ほか：喉頭気管食道裂 (Laryngotracheoesophageal Cleft) の 1 手術例. 日 小外会誌 $9: 708,1974$

3 ) Blumberg JB, Stevenson JK, Lemire RJ, et al. : Laryngotracheoesophageal Cleft, the embryologic implications : Review of literature. Surgery 57 : 559 $\sim 566,1965$

4) Pettersson G : Laryngotracheoesophageal Cleft. Z Kinderchir $7:$ 43 49, 1969

5 ) Wolfson PJ, Scholoss MD, Guttman FM, et al. : Laryngotracheoesophageal Cleft. Arch Sug 119 : $228 \sim 230,1984$

6 ）川城信子：気管食道裂。小児外科 $22: 61,1990$
7 ) Donahoe PK, Gee PE : Complete Laryngotracheoesophageal Cleft : Management and repair. J Pediatr Surg $19: 143,1884$

8 ) Horimoto Y, Yosizawa M: Intraoperative one-lung ventilation for total Laryngotracheoesophageal Cleft. Middle East J Anesthesiol $10: 519 \sim 525,1990$

9) Hof E, Hrsing J, Giedion A, et al. : Deleterious consequences of gastroesophageal reflux in cleft larynx surgery. J Pediatr Surg 22：197, 1987

10）石関しのぶ, 原光彦, 嶋田優美ほか：Laryngotracheoesophageal Cleft $の 1$ 例. 周産期医学 $20: 192$, 1990

\author{
著者連絡先 松山尚弘 \\ T 329-04 栃木県河内郡南河内町薬師寺 3311 \\ 自治医科大学集中治療部
}

\title{
A Case of Anesthesia for Radical Operation for Type 3 Laryngo-tracheo-esophageal Cleft (LTE cleft)
}

\author{
Naohiro MATSUYAMA**, Kouichi HIROKI*, Takanori FUJIWARA*, \\ Tatsuya KUBOTA**, Kazuei OOTAKE** \\ *Department of Anesthesiology, Kanagawa Children's Hospital \\ **Department of Intensive Care, Jichi Medical School
}

\begin{abstract}
Type 3 Laryngo-tracheo-esophageal cleft (LTE cleft) is a rare anomaly, commonly complicated by aspiration pneumonia and other respiratory diseases which may lead to death. This case was a 3,000 $\mathrm{g}$ female baby who had undergone ligation of abdominal esophagus and jejunostomy eight days after birth. On the 30 th day after birth, we performed a radical operation for her anomalies under intratracheal anesthesia. We used ECMO (extracorporeal membrane oxygenation) via her jugular vein and carotid artery so that we did not need to ventilate her during surgery on her trachea. A specially-made $\mathrm{Y}$-shaped intratracheal tube was placed during the operation in the trachea in such a way that both branches of the $\mathrm{Y}$ stayed in the bronchi while the stem protruded from the nasal orifice for ventilation. The patient was mechanically ventilated for two weeks after surgery, then the Y-shaped tube was safely extubated.
\end{abstract}

The Journal of Japan Society for Clinical Anesthesia Vol. 15 No. 4, 1995 